\title{
USAGE OF CREATIVE TECHNOLOGIES IN TEACHING ENGLISH LANGUAGE IN THE INTERCULTURAL COMMUNICATION PROCESS
}

\author{
Olena Iaburova \\ Candidate of Pedagogical Sciences, Associate Professor \\ of Primary Education Theory and Practice Department \\ SHEE "Donbas State Pedagogical University" \\ Sloviansk, Donetsk region, Ukraine \\ http://orcid.org/0000-0003-4633-2900 \\ primetime3311@gmail.com
}

\begin{abstract}
The article under consideration is devoted to studying the effectiveness of intercultural communication of Ukrainian students at higher educational establishments. The question of using social and pedagogical, methodological and linguistic means in the process of intercultural communication is observed through studying a foreign language.

The author stresses that the content of intercultural communication is based on raising students' positive attitude to the country whose linguistic culture is studied, a high level of studying informative process value, providing conditions for authentic communication at the intercultural level, assessing and analyzing events which give an opportunity for a future specialist to be integrated in the open intercultural space. The aim of the article is to analyze theoretical and methodological preconditions of using creative technologies while studying English in the process of intercultural communication in a specific way. The author also focuses on defining and describing the main constituent parts of the strategies how to implement intercultural communication through studying languages.

Taking the results of the done theoretical analysis into account, the author recommends the set of special linguistic exercises, designed according to the main creative approaches to studying a foreign language in the process of intercultural communication.
\end{abstract}

Key words: intercultural communication; creativity; linguistic culture; studying technologies; information values.

Setting the problem. Over the past two decades, the term "intercultural communication" has become a truly widespread, universally recognized and interdisciplinary scientific definition. It is considered from various points of view in the scientific works of prominent national and foreign philosophers, psychologists, sociologists, linguists, and other representatives of a scientific world. Quite naturally, modern pedagogical science is not an exception in this disciplinary series. The problems of intercultural communication in the process of educational and professional work are the subject of social pedagogy as a branch of a pedagogical science and modern scientific discipline. The use of innovative learning technologies in the process of intercultural communication, in particular creative learning technologies is under particular observation.

The analysis of recent research and publications. Before considering the main problems of intercultural communication, its specificity and its use in the process of studying foreign languages, a special attention should be paid to the socio- 
pedagogical and general scientific features of the content laid down in this scientific definition. Thus, A. L. Sventsytskyi, considering culture as an interdisciplinary, general scientific phenomenon, namely, “... as a set of material and spiritual values inherent in various communities, social groups in relation to specific historical periods ...", shifts the emphasis in the direction of the spiritual activity of representatives of certain communities and ethnic groups arguing that culture should be considered as "... a phenomenon that is related to the sphere of spiritual activity of people, as a set of spiritual values and norms inherent in certain social communities" [4, p. 202].

As it is noted by the vast majority of foreign researchers, intercultural communication as a scientific definition and discipline begins to appear in the 20th century, when a well-known scientific monograph "Culture as Communication" by E. Hall and D. Trager appears. Later, in his own work E. Hall develops the idea of multicultural communication as a special field of human relationships where the close link between culture and communication is directly realized [6, pp. $7-10]$.

Speaking about intercultural communication, it is always contrasted with the diverse cultural formations of its participants, so as a sign of intercultural communication R. Porter in his scientific monograph "Intercultural Communication" notes in particular the following: "... intercultural communication takes place only when the producer of a particular message is a representative of one culture, and the recipient of the message is a representative of a different one" [7, p. 15]. The main difficulties in solving the problems of intercultural communication in scientific research are, firstly, the interdisciplinary nature of this field of knowledge (intercultural communication and its related phenomena and laws simultaneously serve as subjects of research in psychology, pedagogy, linguistics, sociology, culturology, etc.) and, secondly, the vagueness of the definition of intercultural communication phenomenon.

According to I. Ivanova, who devotes her article "Forming the informational background of intercultural communication" to the necessity of creating a professionally oriented textbook in the process of future specialist training. Implementing the cultural approach in a professionally directed textbook primarily involves the following aspects: educating the students with a positive attitude towards the country, the linguistic culture of which is being studied; the high level of informational value, especially in the array of lexical units; providing the conditions for authentic communication at the intercultural level; selecting the cultural content of the textbook illustrating the functions of certain phenomena according the background of a broad social context; comparing the cultures relating to the native language and culture; assessing and analyzing the phenomena that will enable the future specialist to be oriented in normative and non-normative situations of intercultural communication; taking the professional needs of the learner into account; observing the experience of students, which they possess at a certain stage of mastering a new linguistic culture [1].

As T. Kopetchuk remarks in his programmed article "Socio-cultural tasks as a means to replenish the general cultural competence of the future foreign language teacher", the quality of the professional training of the future foreign language teacher mainly depends on the level of his or her general cultural, socio-cultural and 
communicative competencies. Having mastered the sociocultural competence as an important component of professional competence while being a student, the future teacher will significantly increase his own general cultural competence and will not have any difficulty in developing his students' socio-cultural competence [2].

As O. Pershukova notes in her publication "On the Way to Intercultural Consciousness", studying the main stages of the development of the socio-cultural component of the content of teaching foreign languages, perfect mastering a foreign language in the modern society implies profound knowledge of the socio-cultural component of the country of its origin. In today's conditions of European integration and internationalization of many aspects of life, the problem of communicating using a foreign language with everyone who speaks this language becomes of particular importance. Therefore, the modern approach to structuring the socio-cultural component of the content of education is characterized by the fullness of elements of the intercultural dimension, which means the development of intercultural consciousness among students and involves the possession of intercultural skills [3].

According to M. Sidun's point of view expressed in the programme article "Forming the professional competence of a foreign language teacher", the whole speech development of the future teacher of a foreign language is determined by the qualitative level of his speech activity, in the process of his self-realization as the form of self-development, the achievement of a separate goal, comprehension the essence of professional activity. The social component, according to the author, is the teacher's understanding the essence of social problems, public maturity and civil responsibility, etc. [5].

Setting up the tasks. The purpose of our work is to analyze the main theoretical and methodological prerequisites for studying the specificity of using creative technologies of teaching English in the process of intercultural communication. In accordance with the goal of the study, the following tasks were identified: 1) to determine the modern scientific and theoretical preconditions for the study of intercultural communication in the process of educational activity; 2) identify and describe the main components of the strategy of implementing the intercultural communicative space in the process of learning foreign languages; 3) using creative learning technologies of foreign languages, developing and offering a set of special exercises that can be used in the process of intercultural communication while learning English.

The main material presentation. Creative ways to teach English both deliver outstanding results and require every day inspiration and innovative and specific approaches for this kind of lessons. Teaching through the arts manages to maintain high expectations from teachers while preparing and giving lessons. In this article some techniques to challenge creative teaching will be considered and shared.

The first activity to be observed is immersion activity which is perfect in creating positive environment in teaching English in the process of intercultural communication. So students' access stories, poems and other texts in their minds, their imagination should be fully involved in a range of creative activities before reading the 
text. Through painting the main characters of the piece for reading, listening to music composition, creating the mood of the whole story, making sculptures, playing little roles in dramas, describing the events in an imaginative way students become fully prepared and excited about the reading journey ahead of them. Besides, in this creative process students can have a chance to share the vocabulary connected with the text ahead, express ideas, analyze concepts, make a prediction about the plot or the end of the story which gives their reading fresh meaning and purpose. The reading itself stops being a separated piece of the text from the book, an exercise "to read, translate and comprehend" but becomes the continuation of their imaginative work.

Let us give an example of a short scenario of the lesson "International Day" for a group of Ukrainian students.

Step1. Start the lesson in an unexpected way for students with a music piece or a little video to attract students attention and deep them into the atmosphere of the "International Day".

Step 2. Turn the students of the class into international guests imagining their names, personal characteristics, surrounding, habitual actions, costumes. The work of this type gives you a good chance for revising the vocabulary on the "topics "Personal Details", "Emotions", "Customs and Traditions", "Everyday Routine" and so on.

Step 3. Involve students in the creative work the teacher is talented at. It can be painting comics of one day from the international students' day, presenting national dances in the style, making drafts of national costumes and telling their life story, singing international songs.

Step 4. Read the text or poem which is a focus of your lesson. Do comprehensive exercises trying to correlate the tasks with the grammar and vocabulary discussed earlier at the lesson.

Step 5. Do productive activity. Let students write or act their international guests' profiles and present the results of their work for the other student groups.

Another approach to track fantastic English results is to provide students with a clear purpose to all reading and writing tasks. The aims to do a piece of writing can include an invitation to teachers or lectures to visit a student meeting, an email to the author of the article in the magazine or an essay for a university newspaper competition. In this case students know why the quality of their writing matters because there will be a real reader for their published work. Assessing their writing can be done individually or in front of the class to demonstrate the importance of the work they have done.

One more effective way of making students work significant as well as providing a real incentive is to publish their writing in a range of different ways.

University bookmaking project can exemplify this. Following a university advertisement competition on book publishing, every group presents their own shared book: one example can be an anthology of short real life stories composed by first year students. Their stories could be mounted on handmade paper in the form of a diary, accompanied with student photographs to make them look more attractive to read. The 
effort pupils put into their work is immense, and the results are stunning to be presented for other students.

The pride in the work done by students is usually clear to see. The published books can be used as reading materials during the classes. They can be presented by the author themselves in the form of an interview or a lesson where the students who write the text can play different roles.

Where possible, learning interactive and communicative skills in English is linked with other subjects to create a closed circle the idea of which is to present different notions as one-picture sight where English is regarded as an instrument for basic discussion, in the process of intercultural communication. Two ranges of subjects, presented lower, can be regarded as the illustration of this integration process. The first set of notions: Nature, Seasons, Art, Sport, Music, Surrounding world. The next set of notions can be composed as the following one: Ukrainian folklore, Music phonics, Art colour symbols, History factsheets, Making up lyrics, Psychology, Mentality description.

Teaching reading is a very complicated process. As students fluency in reading increases, it`s hard to know what reading skills need to be taught. In everyday life, students tend to do much more extensive reading which is fluent, faster reading without careful attention to the details for pleasure, entertainment, specific purposes or gist. As a result, specific reading strategies are formed explicitly to the class that makes them a little bit chaotic, spontaneous, based on intuition rather than clear understanding reading strategies. These could include scanning a text, skimming a text, predicting the end, mapping the story or creating a mental image. A teacher can use "think aloud" method of reading the text which can exemplify to students how these strategies work.

Creative ideas to interpret or model reading strategies could include:

- $\quad$ skip in at the middle and reading one page, predict what happened before, who the people are, where they are;

- $\quad$ allow students to improvise to see how the book character would behave in a totally different surrounding or time period;

- map out the relationships between characters or events sequence, map the story itself and accompany it with lines showing different characters` actions;

- $\quad$ keeping a diary as if you are the main character of the story;

- interview students in the roles of the author of the book or different characters for a chat-show on TV;

- draw the picture of the scene or a series of pictures. After finishing, compare and discuss their differences and similarities;

- choose the passage of the book and blank out some words or exchange them. Ask students to guess what is going to happen by trying to complete the text with the missing words;

- redesign the cover of the book, write the "blurb" on the back cover in another way to make it more attractive for a special group of target readers; 
- put on an act of meeting of the board of directors for a film company, decide if the story is suitable for making a movie, what kind of changes are necessary to be done.

Using drama to motive, inspire and engage students in a creative learning process is also a powerful tool. Using a range of drama techniques expand the students imagination and provide them with the ideas they need to make their writing and speaking presentation sparkle with humour and imagination. Drama techniques include the following types of classroom activities: role-playing, simulating, playing drama games, acting play scripts, preparing improvised drama and acting play scripts. All of these are good ways to expand students' vocabulary, provide a lot of useful speaking practice, open the potential of the shyest students freeing them from the constraints of expected behavior.

Here are some short examples of drama games:

- $\quad$ prepare a set of cards for your students including famous character names (Barak Obama, Angelina Jolie, Michael Jackson, Shakespeare) and different complaints they have being poorly serviced ("the cream source in the fish dish has gone off", "the perfume they bought is smelly", "the room in the hotel doesn 't have a toilet room"). Give them a few minutes to work out their story. Instruct them to meet each other and have a short conversation aimed at explaining their problem, getting some advice or recommendation how it can be solved. Give them a signal to move on to a new place where they meet another person. Afterwards, ask students to sound unexpected solutions to the problems or just retell funny dialogue they had.

- " "freeze" the picture by making students show the scene of a farm life or Black Friday. Students take different positions becoming customer, staff, check-inclerks.

Unfreeze the picture and bring it to life for short improvised dialogues. You can play them separately or simultaneously.

- turn the classroom into the scene by describing the night forest with rustling trees, glooming light of the moon, hair-raising screams of the owl. Get students become people in the landscape. Let the story unfold in any way it can by improvising together with the group of students. The teacher runs this story moving by finding a balance between a live improvisation and the necessity of keeping it under control to ensure that it avoids silly jokes or pointless ideas. To achieve this make your interventions subtle by hinting to some of the participants rather than by interrupting the whole story and offering your way of sequencing events.

Learning the grammar cannot be taught as a special activity in what learning a language is involved. Students need to have exposure to the language, notice and understand items being used, try using language at first repeatedly after the model, more independently in "safe" practical ways being corrected by the teacher or peers and, finally, spontaneously in a speech stream. This is the best way to remember and implement things they have learnt. 
Learning which takes place by exploring shared texts to have grammar concepts, punctuation rules and techniques drawn from and embedding them creatively has more positive impact on using language competently, fluently and accurately than studying and memorizing rules from a grammar book.

There are some possible hints how to teach grammar creatively. Try to keep the atmosphere in the class humorous to involve everybody in practice but a teacher is on the group wave, he could personalize some elements of teaching grammar to make it more appealing accompanied with mine, board pictures, silly postures and personal photos. Make all the practical exercises short but enough to elicit, explore or exemplify grammar content. Communicative values or meaningfulness are not so important in this case to pay a lot of attention. The thing which is more important is drilling a realistic piece of real-world language. Keeping the challenge high, make sure students get practice, not the teacher does.

Write out some sentences using conditionals cut them in half, and put them in two socks or pin them around the class. Let students finish sentences by finding the half by themselves. It can be a random choice that gives both additional excitement to the exercise and opportunity for creativity how to finish the sentence or the matching half among the other students.

1. If you steal the show, it'll be unfair. (you'll be bitten by a wasp)

2. If he breaks the house down, he'll be excited (the roof will be damaged)

3. If you go out with my boyfriend, I'll be furious (I'll bite your nose)

4. If the thunder strikes your house, you`ll be afraid (you`ll get a prize)

Picture dictation could also be one of the methods how to teach grammar creatively. One student describes a picture to work on the present progressive tense while other students, who haven 't seen it, try to draw their own pictures following the description. After that pictures are compared defining differences and similarities and clarifying some details by asking the questions.

Get ready with a set of magazine pictures or real-life photos. In groups students look at the pictures and match the verbs to the pictures of their choice.

Groups swap their sets of picture/verb matches. Now their task is to complete full sentences and attempt to invent the other details to make a story. They do the task orally and present it to the rest of the class.

Stern a story by saying one sentence in the past simple tense, then present a script sheet. As the first stage it could be used for Total Physical Response to make sure the meaning of the verbs are clear for the students in the class.

Script sheet for making up a story

- Disco info

- Put on your best clothes 
- Look at the mirror

- Nice you are!

- Meet you friends

- Loud music

- Smoke machine works!

- Froze to the floor - you see her!

- How beautiful she is!

- Not confident enough

- Love at first sight!

- At last - start conversation

- Hurry! You have her number
- Put it in your jeans pocket

- Come back home

- Fall asleep

- See her in dreams

- Morning

- No jeans in sight

- Oh no! Mom was in your room.

- Washing mashie sounds

- Rush downstairs

- Too late!

- Nothing but pieces of wet paper

At the first stage of learning English, phonics is streamed, so all students can benefit following different kinds of activities, making maximum progress as a result. These activities should be fun and multi-sensory to make classroom work enjoyable and useful.

Conclusions. Summarizing the above, we note that:

1) effective intercultural communication is the involvement of participants in a communicative act by the following knowledge systems: knowledge of a symbolic system in the terms of which communication takes place; knowledge of the basic principles of the system of the world, consisting of the personal individual experience; basic fundamental knowledge of the world that exists in all people; other knowledge that personality has, due to belonging to a certain ethnic group, culture, religion, etc;

2) the implementation of intercultural communicative space in the process of studying foreign languages implies the education of students with a positive attitude towards the country, whose linguistic culture is studied; high level of informational value, especially in the array of lexical units; providing the conditions for authentic communication at the intercultural level; comparing cultures in reliance on native language and culture; assessment and analysis of phenomena that will enable the future specialist to be oriented in normative and non-normative situations of intercultural communication; taking into account the professional needs and the experience of students, which they possess at a certain stage of mastering a new linguistic culture;

3 ) based on the results of the theoretical analysis, a number of special exercises are proposed that are based on the main approaches of creative technologies of teaching English in the process of intercultural communication.

\section{СПИСОК ВИКОРИСТАНИХ ДЖЕРЕЛ}

1. Іванова, I. (2008). Сформувати інформаційне тло міжкультурної комунікації. Іноземні мови у навчальних закладах, 1, 46-50.

2. Копетчук, Т. (2008). Соціокультурні завдання як засіб поповнення загальнокультурної компетентності майбутнього вчителя іноземної мови. Іноземні мови $у$ навчальних закладах, 1, 56-59. 
Usage of Creative Technologies in Teaching English Language in the Intercultural Communication Process

3. Першукова, О. (2008). На шляху до міжкультурної свідомості. Іноземні мови в навчальних закладах, 1, 61-68.

4. Свенцицкий, А. Л. (2008). Краткий психологический словарь. Москва, Россия: ТК Велби, Изд-во Проспект.

5. Сідун, М. (2008). Формувати професійну компетентність вчителя іноземної мови. Іноземні мови у навчальних закладах, 4, 115-124.

6. Hall, E., \& Trager, D. (1954). Culture as Communication. New York, N.Y.

7. Porter, R. (Ed.). (1988). Intercultural communication: A 5-th edition. Belmong: Wadsworth Publishing Company.

\title{
ВИКОРИСТАННЯ КРЕАТИВНИХ ТЕХНОЛОГІЙ НАВЧАННЯ АНГЛІЙСЬКОЇ МОВИ В ПРОЦЕСІ МІЖКУЛЬТУРНОЇ КОМУНІКАЦІї
}

\author{
Олена Ябурова \\ кандидат педагогічних наук, доцент \\ ДВНЗ “Донбаський педагогічний університет” \\ м. Слов’янськ, Донецької області, Україна. \\ http://orcid.org/0000-0003-4633-2900 \\ primetime3311@gmail.com
}

\begin{abstract}
Анотація. Стаття присвячена вивченню ефективності міжкультурної комунікації українських студентів. Розглядається питання соціально-педагогічного, методичного та лінгвістичного забезпечення цього процесу і вивчення його ефективності через вивчення іноземної мови у ВНЗ України. Автор статті підкреслює, що в основі міжкультурної комунікації лежить виховання у студентів позитивного ставлення до країни, лінгвокультурі, що вивчається, високий рівень інформаційної цінності навчального процесу, забезпечення умовної для автентичного спілкування на міжкультурному рівні, оцінка та аналіз явищ, які дають можливість майбутньому спеціалісту інтегруватися у відкритий міжкультурний простір. Грунтуючись на результатах теоретичного аналізу, автор статті пропонує ряд спеціальних лінгвістичних вправ, побудованих на основних підходах креативних технологій вивчення англійської мови в процесі міжкультурної комунікації.
\end{abstract}

Ключові слова: міжкультурна комунікація; креативність; лінгвокультура; технології навчання; інформаційні цінності.

\section{ИСПОЛЬЗОВАНИЕ КРЕАТИВНЫХ ТЕХНОЛОГИЙ В ОБУЧЕНИИ АНГЛИЙСКОМУ ЯЗЫКУ В ПРОЦЕССЕ МЕЖКУЛЬТУРНОЙ КОММУНИКАЦИИ.}

\section{Елена Ябурова}

кандидат педагогических наук, доцент

ГВУЗ “Донбасский государственный педагогический университет”

г. Славянск, Донецкой области, Украина.

http://orcid.org/0000-0003-4633-2900

primetime3311@gmail.com

Аннотация. Данная статья посвящена изучению эффективности межкультурной коммуникации украинских студентов. Рассматривается вопрос социально-педагогического, методического и лингвистического обеспечения данного процесса и изучения его эффективности через изучение иностранного языка в ВУЗах Украины. Автор статьи

Професіоналізм педагога: теоретичні й методичні аспекти. - Вип. 7. - Слов'янськ, 2018. 
Usage of Creative Technologies in Teaching English Language in the Intercultural Communication Process

подчеркивает, что в основе межкультурной коммуникации лежит воспитание у студентов позитивного отношения к стране, лингвокультура которой изучается, высокий уровень информационной ценности учебного процесса, обеспечение условий для аутентичного общения на межкультурном уровне, оценка и анализ явлений, которые дают возможность будущему специалисту интегрироваться в открытое межкультурное пространство. Основываясь на результатах теоретического анализа, автор статьи предлагает ряд специальных лингвистических упражнений, построенных на основных подходах креативных технологий обучения английскому языку в процессе межкультурной коммуникации.

Ключевые слова: межкультурная коммуникация; креативность; лингвокультура; технологии обучения; информационные ценности.

\section{REFERENCES}

1. Ivanova, I. (2008). To form an informational background for intercultural communication. Inozemni movy u navchalnykh, 1, 46-50.

2. Kopetchuk, T. (2008). Social and cultural tasks as a means of replenishing the general cultural competence of the future teacher of a foreign language. Inozemni movy u navchalnykh, 1, $56-59$.

3. Pershukova, O. (2008). On the road to intercultural consciousness. Inozemni movy u navchalnykh, 1, 61-68.

4. Cvencickij, A. L. (2008). Brief psychological Dictionary. Moscow, Russia: TK Velbi, Izd-vo Prospekt.

5. Sidun, M. (2008). Form the professional competence of a foreign language teacher. Inozemni movy u navchalnykh, 4, 115-124.

6. Hall, E., \& Trager, D. (1954). Culture as Communication. New York, N.Y.

7. Porter, R. (Ed.). (1988). Intercultural communication: A 5-th edition. Belmong: Wadsworth Publishing Company.

Матеріали надійшли до редакції 22.05.2018 р. 